\title{
Analysis of Mongolian Students' Common Translation Errors and Its Solutions
}

\author{
Changhua Zhao ${ }^{1}$ \\ ${ }^{1}$ Department of College English, Inner Mongolia the University for the Nationalities, Tongliao, China \\ Correspondence: Changhua Zhao, Department of College English Teaching, Inner Mongolia University for the \\ Nationalities, Tongliao city, Inner Mongolia, China. Tel: 86-137-399-420-99. E-mail: \\ zhaochanghua1979@163.com
}

Received: December 17, 2012 Accepted: January 6, 2013 Online Published: February 1, 2013

doi:10.5539/elt.v6n3p78 URL: http://dx.doi.org/10.5539/elt.v6n3p78

\begin{abstract}
In Inner Mongolia, those Mongolian students face lots of difficulties in learning English. Especially the English translation ability of Mongolian students is a weak point. It is worth to think a problem that how to let our students use the English freely on a certain foundation. This article investigates the problems of Mongolian English learners by analyzing some errors in their English-Chinese translation in three ways. Such as their inflexible use of translation skills, mistakes in idiomatic usage, inflexible and boring statements and the lack of knowledge in cultural background. The paper also offers some solutions to the problems.
\end{abstract}

Keywords: Mongolian students, English translation, problems, solutions

\section{Introduction}

Since reform and opening, China's expectations of its students increased due to the development of the market economic system, expansion of foreign exchanges, and entrance into the WTO. Now, more than before the universal language, English, is needed. The goal of English teaching in universities is to train the students to comprehensively use the language in listening, speaking, reading, writing, translation etc. It is also helpful for students' effective communication. While teachers should pay attention to the students' English knowledge learning, attention should also be paid to the students' knowledge application. One reflection of application is learning how to translate. However teachers and students are faced with many challenges, especially Mongolian students in Inner Mongolia. Because Mongolian students who attend university in China must learn Chinese to take their classes. Their Chinese proficiency is low, learning English by using Chinese to translate becomes a much more difficult problem. As a teacher, it is a challenge that how to deal with the English and Chinese double communication difficulties in teaching. So it weakened or even buried the potential function of translation that can promote foreign language teaching. This article wants to find out those universally existing and always seen problems by analyzing Mongolian college students' English-Chinese mistranslation. And it also puts forward some solving methods. Nowadays in Inner Mongolia, it is teachers' qualities that are paid much more attention than that ever before. English teaching in China has been emphasized quite universally. But people especially in minority area like Mongolia's focus is still on the rate of admission into higher grade schools. English teaching in this area hasn't received much attention as it should do. Actually, the point of the effective language teaching is a group of active comprehensive teachers and communication skill should be regarded as an important part of teachers' development. Teachers play important role in motivating students' learning attitude, improving students' motivation and reducing students' anxiety. Teachers who are skilful in communication can be helpful for the development of students' learning, help students control passive attitude towards disappointing parts that appeared in language learning procedure, avoid going far away from what they are learning, and a lot of advantages will come from this.

\section{The Current Situation in Universities for Mongolian Students}

Students' English levels are various in universities in Inner Mongolia. Their English learning experience varied from three years to six years. Mongolian students in Inner Mongolia learn Chinese as a second language in their senior middle school, and learn English as the third language in middle school and universities. Therefore when teachers teach English and explain difficult point in Chinese, they will feel it hard for them to catch up with. It's even difficult for them to understand Chinese comprehensively not to mention the third language English. They 
misunderstand the teacher's idea at times. In this area, teachers who can understand Mongolian language are extremely needed. If only teachers can understand students first, they can build better teaching and learning structure, which is helpful for students' language learning. But most teachers are Han nationality in universities, they undertake the majority of teaching tasks, they will teach a Mongolian class, too. Problems are always existing because in China, teaching materials are written either in Chinese or in English. To these Mongolian students, Mongolian teachers who teach English can not solve the problems. Mongolian students are not so good at communication as Chinese students, and they have no enough time to learn English thoroughly. The above are also the reasons why there are so many difficulties in their English learning. Most Mongolian students live in remote areas and they never meet with so many strangers. They need to adapt to new surroundings after they enter university. In their hometown, they speak their mother tongue, Mongolian, and a little Chinese most of the time. They do not have much chance to speak Chinese either. When they are in university, they will have Mongolian classmates who is intended to communicate with them in Mongolian, and or else they communicate with others in Chinese. They rarely have chance to use English, which is a hinder to language learning. Teachers are required to speak English or Chinese in class. Teachers usually tell the important and difficult point in Chinese. To students who are not very good at Chinese, learning English from Chinese teachers becomes another difficult part. While they are facing the former difficulties, they are too timid to ask questions or consult teachers after class. Students are inactive in class. They tried to avoid contacting with teachers directly. Their interest and motivation become weaker and weaker. Some even lose their interest in learning English completely. Not only their study but also their whole university life will be affected by the subject. Teachers who can understand Mongolian can get the maximum profits in Mongolian students' English learning. They understand the differences hence they can think over important factors when they assigning homework to students. They can choose appropriate material for students to improve their levels.

\section{Analysis of Mongolian Students' English-Chinese Mistranslation}

\subsection{Inflexible Use of Literal Translation and Free Translation}

One problem Mongolian students have when translating is that they do not understand sentences comprehensively. They do not give full consideration to the contextual meanings and translate sentences individually and isolated from context. Students usually use word for word translation too much or incorrectly within sentences. For example one student's translation of "a big name" is, “大名”. A more accurate translation is: “显赫的名字”. For “a parent child” , a student translated it as “一对父母和孩子” when this phrase should be translated as “自立的孩子”. A student's translation of “he is the last man to accept a bribe” is “他是最后一个受 贿赂的人” when it should be “他绝不会受贿” instead. Another example would be a student's translation of “he is the last man for such a job,” “他是上一个做过这样工作的人”. Whereas “他最不适合这项工作” better portrays the English meaning. A student may translate "this is the last place where I expected to meet you" as “这是我最后想要见到你的地方” but a better translation is “我怎么也没有想到会在这个地方遇到你.” This kind of translation is very difficult to achieve the correct use of the language, not to mention the effective communication.

\subsection{Mistakes in Idiomatic Usage}

When translating, students put the English word into the corresponding Chinese vocabulary instead of doing it with exact, vivid expressions, which results in a lot of defects.For example a student may translate "A beautiful form is better than a beautiful face; a beautiful behavior is better than a beautiful form.” as “美丽的外形胜过美 丽的脸蛋, 美丽的行为胜过美丽的外形.” This word-for-word translation resulted in mistake in the sentence in other words, doesn't the Chinese words “外形”refer to the word “脸蛋”? Therefore, the direct translation of words is not enough to make an accurate translation of these sentences. Word meanings are very complex, and it can be said that no dictionary has all the meanings of a word take out space. A word in different contexts and cultural backgrounds can have completely different meaning, so for example, the sentence, "I stayed till noon, when I went home.”, student's translation is “我一直待到中午，当我回家的时候.” When it should be “我一直 待到中午然后就回家了.” Student's translation of “When the teacher had left the classroom, the pupils started talking” is “当老师离开教室的时候，学生们开始说起话来了.” but the better translation should be “老师离开 教室以后，学生们就喧哗起来.” Translation is a kind of creative procedure. Just using the corresponding Chinese-English vocabulary leaves the translation full of holes.

\subsection{Inflexible and Boring Statements}

Evidence of Mongolian students' lack knowledge of the basic translation theory can be seen in their daily exercises. Every language has differences in expression. Compared with other students, it is much more difficult for them to overcome the three differences from Mongolian to Chinese and from Chinese to English. Hence the 
use of language is dull, and they cannot break through the meaning of word usage because of some problems in understanding. For example, 1)A student's translation of “It's a good father that knows his son.” is “他是一个好 父亲，他很了解他的儿子.” when it should be “就算是最好的父亲，也未必了解自己的儿子.”In the student’s translation, it appeared several "him", which sounds like a lot of repetition. The language used here doesn't seem exciting, concise and comprehensive enough. 2) A student translated the sentence "I have no opinion of that sort of man.” as “对于像他那样的人我没有意见.” But the better translation should be “我对这类人很反感.”In the translation of this sentence, students dare not break through the way of thinking about the words meaning, which led to the wrong understanding. 3) A student's translation of “You look darker after the holiday." is “假期之后你 看起来更黑了.”This sentence should be translated as “假期过后你看上去更健康了.”

\subsection{The Lack of Knowledge in Cultural Background}

Cultural background is the basis of learning and communication, if you do not understand the cultural background, you can easily make mistakes in translation and communication which could lead to contradictions and conflicts. For example, students cannot understand why“open Pandora 's Box"translated as“打开潘多拉的 盒子” without the knowledge of cultural background. The classical allusion originally means opening the scourge of end, therefore it is usually used to describe the beginning of something evil. "Achilles heel": Achilles' heel is usually fatal. "Wooden Horse of Troy" refers to a false thing. "Greek Gift": Greek gift means that there is no good accepting too many gifts. "Helon of Troy": it represents the "troubles" and the "femme fatale" etc. If we do not understand the cultural background in the case, we can not skilfully make use of these things in our translations.

\section{Basic Solutions}

\subsection{Effective Student-Teacher Communications}

Above all, it is very important for students to understand their teachers. Therefore, a group of minority teachers who are experts in effective communication should be cultivated. These teachers can help the Chinese Mongolian students communicate with their teachers in Chinese or Mongolian, their native language, if necessary. The teachers can help the students choose the specific meanings of words, phrases, or idioms within the sentences according to the specific language environment. Consider the word "muttering" in this example, "Fancy all these inexperienced muttering young actors play leading parts in the West End." In this sentence, “muttering" is translated as “喃喃自语的”, that would be quite wrong. Depending on the context, the word can be correctly translated as “连台词都念不清楚的”. The entire translation should be, “试想那些毫无经验的，连 台词都念不清楚的年轻演员们, 居然在伦敦西区大舞台上当起主角来.”

\subsection{Strengthening the Necessary Grammar Training}

Most Mongolian students do not study English during middle school before they enter the university. English is required course in the University in China, so there was a gap in their English education as compared to other Chinese students. To start their English language learning, teachers should begin with grammar instruction. Adults are good at comprehension. When translating, it is also necessary to do syntax analysis. Such as, "He pretends to know her better than he would, if he were a close friend of hers.”他装出一副对他深有了解的样子, 就像她是他的密友。(实际上他不是她的密友.) “He is braver than wise.” 他有勇无谋。“That 's more than I can tell.” 那我就不能多讲了, etc.

\subsection{Encouraging Students' Flexible Use}

Translation is a creative process, so we must encourage students to think creatively while they should be faithful to the originals. According to the differences of cultural background, we can get perfect translation of sentences or passages. The way of translation and the method are very flexible, and English words are also multivariate. To get perfect translation, sometimes the translator need to omit some words, or sometimes add some words. In this way we can be more close to the original expression. For example, 1) The students were on tenterhooks before the examination began. 开始考试前, 学生们心里七上八下. 2) I found him on tenterhooks when he was waiting for his girl friend.我发现他在等女友时显得局促不安. 3) He was on tenterhooks of expectation during our conversation. 在我们谈话时, 他因为有所期待而如坐针毡.

\section{Conclusion}

Based on the analysis of the mistakes of Mongolian students' translation practice, we can see that English teaching in the minority regions still has a long way to go. Translation is an important way to test the students' understanding. Teaching requirements will be another key point which influence the language learning process so teachers in minority area should be trained to motivate students to get to certain standard.To improve students' translating abilities, culture should be studied and translation theory should be combined with practice. Learning 
a language is a very complex process. In this procedure, we need to consider plenty of factors. Such as, background knowledge, idiomatic usage and even grammar. Language learning and teaching should be in harmony with each other. Objective theories of language learning is restricting the whole learning and teaching process. In order to raise our translation level to a standard that allows us to communicate effectively, teachers need to continue to explore more suitable teaching methods for Mongolian students, and students need to make painstaking efforts, too. We have to strengthen our understanding of learning language is to communicate well in the process of language learning. In recent years, people pay much attention to the passing rate of CET4 instead of students' practical ability of making use of what they've learnt. In fact, teaching and learning share the equal importance all the way.

\section{References}

Song Tianxi. (2007). New Concepts of Translation - English-Chinese Translation of Practical Tutorial. Beijing, National Defense Industry Press.

Fan Jiacai. (1998). English Rhetorical Appreciating. Shanghai, Shanghai Jiao Tong University Press.

Yang Daliang. (2007). Commercial English Translation Course. Beijing, Peking University Press.

Zhang Peiji. (1995). Course in English-Chinese Translation. Shanghai, Shanghai Foreign Language Education Press.

Shen Yuping, \& Dai Ning. (2006). Practical Course in English-Chinese translation. Beijing, Foreign Language Teaching and Research Press.

Feng Qinghua. (2004). Practical Translation Course. Shanghai, Shanghai Foreign Language Education Press.

Wang Juquan, \& Zheng Lixin. (2004). English-Chinese Contrastive Studies of Languages and Cultures. Shanghai Foreign Language Education Press.

Wang Rongpei. (1997). Comparison and Translation. Shanghai Foreign Language Education Press. 